\title{
Optimization of biomass, total carotenoids and astaxanthin production in Haematococcus pluvialis Flotow strain Steptoe (Nevada, USA) under laboratory conditions
}

\author{
ANA S CIFUENTES, MARIELA A GONZÁLEZ, SILVIA VARGAS, MARITZA \\ HOENEISEN and NELSON GONZÁLEZ
}

Departamento de Botánica, Facultad de Ciencias Naturales y Oceanográficas, Universidad de Concepción, Casilla 160-C, Concepción, Chile

\begin{abstract}
The microalga Haematococcus pluvialis Flotow is one of the natural sources of astaxanthin, a pigment widely used in salmon feed. This study was made to discover optimal conditions for biomass and astaxanthin production in $H$. pluvialis from Steptoe, Nevada (USA), cultured in batch mode. Growth was carried out under autotrophic (with $\mathrm{NaNO}_{3}, \mathrm{NH}_{4} \mathrm{Cl}$ and urea) and mixotrophic conditions (with 4, 8, $12 \mathrm{mM}$ sodium acetate) under two photon flux densities (PFD) (35 and $\left.85 \mu \mathrm{mol} \mathrm{m} \mathrm{m}^{-2} \mathrm{~s}^{-1}\right)$. The carotenogenesis was induced by 1$)$ addition of $\mathrm{NaCl}(0.2$ and $0.8 \%)$, 2) N-deprivation and 3) high PFD $\left(150 \mu \mathrm{mol} \mathrm{m}^{-2} \mathrm{~s}^{-1}\right)$. Total carotenoids were estimated by spectrophotometry and total astaxanthin by HPLC. Ammonium chloride was the best $\mathrm{N}$-source for growth $\left(\mathrm{k}=0.7 \mathrm{div} \mathrm{day}^{-1}, 228-258 \mathrm{mg} \mathrm{l}^{-1}\right.$ and $2.0 \times 10^{5}-2.5 \times 10^{5}$ cells $\mathrm{ml}^{-1}$ at both PFD, respectively). With increasing acetate concentration, a slight increment in growth occurred only at $85 \mu \mathrm{mol} \mathrm{m} \mathrm{m}^{-2} \mathrm{~s}^{-1}$ Light was the best inductive carotenogenic factor, and the highest carotenoid production $\left(4.9 \mathrm{mg} \mathrm{l}^{-1}, 25.0 \mathrm{pg}^{-1 l^{-1}}\right)$ was obtained in cultures pre-grown in nitrate at low light. The $\mathrm{NaCl}$ caused an increase in carotenoid content per cell at increasing salt concentrations, but resulted in a high cell mortality and did not produce any increment in carotenoid content per volume compared to cultures grown at $150 \mu \mathrm{mol} \mathrm{m} \mathrm{m}^{-2} \mathrm{~s}^{-1}$. The highest carotenoid content per cell $(22 \mathrm{pg})$ and astaxanthin content per dry weight $\left(10.3 \mathrm{mg} \mathrm{g}^{-1}\right)$ $(1 \% \mathrm{w} / \mathrm{w})$ were obtained at $85 \mu \mathrm{mol} \mathrm{m} \mathrm{m}^{-2} \mathrm{~s}^{-1}$ with $0.8 \% \mathrm{NaCl}$.
\end{abstract}

Key terms: astaxanthin, carotenogenesis, growth, Haematococcus pluvialis.

\section{INTRODUCTION}

Since the 1930s, the freshwater microalga Haematococcus pluvialis Flotow (Volvocales, Chlorophyceae) has been widely recognized by its ability to accumulate large amounts of the ketocarotenoid astaxanthin (Elliot, 1934), but interest in this alga has been renewed in recent years due to the increasing demand for natural pigments of vegetable origin to be used as a substitute for their synthetic counterparts. Astaxanthin is used as a source of pigmentation for fish in aquaculture (especially salmonids) and for eggs in the poultry industry, but it is also recognized as having a higher antioxidant activity than other carotenoids (Meyers, 1994; Miki,
1991; Kobayashi et al., 1997a). Only a few microorganisms (some species of bacteria, lichens, fungi and microalgae) have been reported to synthesize astaxanthin (Johnson and Schroeder, 1995; Armstrong, 1997), and $H$. pluvialis is one of the most challenging to study, since it is capable of accumulating the highest proportion of astaxanthin in relation to its dry weight: 1.5 to $5.0 \% \mathrm{w} / \mathrm{w}$ (Johnson and Schroeder 1995; Krishna and Mohanty, 1998). Despite this physiological advantage, which has been extensively studied, the published results have discouraged, to some extent, the commercial production of astaxanthin from Haematococcus. This alga exhibits some unfavorable characteristics when compared to other microalgae successfully cultivated 
at commercial scale (i.e., Dunaliella spp., Spirulina spp.) These concerns are mainly related to its slow growth rate and its complex life cycle, exhibiting motile and non-motile cells, solitary and/or grouped in palmella stages (Elliot, 1934; Triki et al., 1997; Lee and Ding, 1994) which is not yet well understood.

To date, it is well known that the accumulation of astaxanthin in $H$. pluvialis is associated preferentially with a morphological transformation of green motile vegetative cells to deep-red nonmotile cysts, and many research efforts have sought to enhance the relatively slow growth rate of the motile vegetative cells: $0.5-0.7$ div day $^{-1}$ (Zlotnik et al., 1993; Chaumont and Thèpenier, 1995; Fan et al., 1994; Barbera et al., 1993; Gong and Chen, 1997; Hagen et al., 2001; Orosa et al., 2001), exceptionally $0.9 \mathrm{div}_{\mathrm{day}^{-1}}$ (Grunewald et al., 1997; Fan et al., 1994; Hagen et al., 2000). Other research efforts have focused on the low maximal cell densities exhibited by this alga at different culture conditions: 1.5 - $2.5 \times 10^{5}$ cells $\mathrm{ml}^{-1}$ (Hagen et al., 1993; Lee and Ding, 1994, 1995; Harker et al., 1996b; Grünewald et al., 1997), more exceptionally $5.5 \times 10^{5}$ cells $\mathrm{ml}^{-1}$ or higher (Kobayashi et al., 1993; Spencer, 1989; Bubrick, 1991; Kakizono et al., 1992). From this point of view, any factor tending to enhance and/or to maintain vegetative growth would not allow astaxanthin cell accumulation, and any astaxanthin inductive condition tends to constrain the algal growth. This pattern of cell growth and carotenoid accumulation has generated two productive strategies for growing Haematococcus: one, in a single step using a suitable medium (sub-optimum) for both biomass and astaxanthin production, where astaxanthin is accumulated while cells are growing, and the other, in two consecutive steps, the first under optimal conditions for vegetative growth followed by another for astaxanthin production in non-growing cells.

There exists a great debate concerning the function of secondary carotenoids in $H$. pluvialis and where and when they are synthesized. Numerous studies have suggested a strict relationship between astaxanthin accumulation and the formation of resting cells (cysts) (Boussiba and Vonshak, 1991; Kobayashi et al., 1991). Other works, however, have clearly shown astaxanthin accumulation in the motile vegetative stage (Lee and Ding, 1994; Chaumont and Thèpenier, 1995; Grünewald et al., 1997; Sun et al., 1998; Hagen et al., 2000). Currently, commercial production of astaxanthin by $H$. pluvialis has been reported based on both strategies using a two-step culture [Cyanotech Corporation and Aquasearch Inc., Microbio Resources Inc., and Algatec Inc. (Bubrick, 1991)] and/ or a single step process [Microgaia Inc. (Olaizola, 2000)] and both processes are carried out under photoautotrophic conditions. Although mixotrophic metabolism in this alga has been studied and documented (Borowitzka et al., 1991; Kobayashi et al., 1992; Gong and Chen, 1997), and heterotrophic growth has been reported in some strains of $H$. pluvialis (Kobashayi et al., 1992; Hata et al., 2001), these conditions have not been applied in cultures at commercial scale.

The present study was aimed at optimizing the phototrophic requirements for growth of $H$. pluvialis in relation to the nitrogen source and the addition of sodium acetate to estimate mixotrophic growth in batch cultures at different photon flux densities. From the various factors inducing astaxanthin production reported in the literature, the addition of salt, the deprivation of nitrogen in the medium and the higher irradiance, were examined here. The strain under study (from Steptoe, Nevada, USA) has not been studied before, and these results constitute the first set of data to compare it with other strains of $H$. pluvialis. Ranges of optimal culture conditions found for different strains may show great disparity. Results obtained by our working group on different strains of Dunaliella salina reinforce this assertion (Cifuentes et al., 1992, 1996a, b, 2001; Gómez et al., 1999).

\section{MATERIALS AND METHODS}

Organism, growth medium and maintenance conditions of the inocula

Haematococcus pluvialis (Flotow) strain Steptoe (Nevada, USA) was donated in 
unialgal condition by Dr. Ralph Lewin in 1989, and since that date has been maintained in the Microalgal Culture Collection at the University of Concepción, Concepción, Chile. The alga was initially grown in Bristol medium (Starr and Zeikus, 1987) in a static continuous culture regime (batch mode) under the following conditions: temperature of $23^{\circ} \pm 2^{\circ} \mathrm{C}$, photon flux density (PFD) of $35 \mu \mathrm{mol} \mathrm{m} \mathrm{m}^{-2} \mathrm{~s}^{-1}$, photoperiod of 16:8 (L:D), without aeration but manually agitated twice a day. The stable growth parameters obtained under these conditions were: $\mathrm{N}_{\mathrm{i}}=10^{3}$ cells $\mathrm{ml}^{-1}$, $\mathrm{N}_{7 \text { davs }}=5 \times 10^{4}$ cells $\mathrm{ml}^{-1}, \mathrm{k}=0.8 \mathrm{div}_{\mathrm{day}^{-1}}$, $\mathrm{v}=10 \mathrm{ml} \mathrm{v}$ inocule $=200 \mu \mathrm{l}$. In these conditions, the inocula for the experiments consisted of motile vegetative cells (98\%) and cysts $(2 \%)$.

\section{Optimum nitrogen source for growth}

Three sources of nitrogen were tested in the medium: namely, sodium nitrate, ammonium chloride, and urea at concentrations of $2.9 \mathrm{mM}$. The cultures were grown in $500 \mathrm{ml}$ Erlenmeyer flasks with $200 \mathrm{ml}$ of medium, under two different continuous PFD: 35 and $85 \mu \mathrm{mol} \mathrm{m} \mathrm{m}^{-2} \mathrm{~s}^{-1}$ (supplied by fluorescent cool daylight lamps), at $23^{\circ} \pm 2^{\circ} \mathrm{C}$, without aeration and agitated manually twice a day. The $\mathrm{pH}$ of the medium was adjusted to 6.0 after being autoclaved, and the initial cell density was $2 \times 10^{3}$ cells $\mathrm{ml}^{-1}$. During growth, the $\mathrm{pH}$ was not modified except in the cultures growing with ammonium. To these, drops of $\mathrm{NaOH} 1 \mathrm{~N}$ were added every other day in order to maintain the $\mathrm{pH}$ between 5.0 and 6.0 , because of the acidification from algal metabolism $\left(\mathrm{NH}^{+}{ }_{4} \rightarrow \mathrm{H}^{+}+\mathrm{N}\right.$-algal $)$. The $\mathrm{pH}$ reached values as low as 3.5 , between one control and another, but the healthy condition of the cultures was not affected. The algal dry weight was determined after 13 days of cultivation by filtering $20-\mathrm{ml}$ aliquots through Millipore filters of $5 \mu \mathrm{m}$ pore size, washing in distilled water, and drying at $100^{\circ} \mathrm{C}$ to constant weight $(24 \mathrm{~h})$. Cell density was also estimated in each nitrogen source in order to have estimations on a cell and volumetric basis. The relative number (\%) of motile vegetative cells and cysts was also registered. The experiments were carried out in triplicate.

\section{Mixotrophic growth with addition of sodium acetate}

The concentrations of the sodium acetate assayed were 4,8 and $12 \mathrm{mM}$, with an initial $\mathrm{pH}$ adjusted to 6.0. Each of these acetate concentrations was tested at two continuous photon flux densities, 35 and $85 \mu \mathrm{mol} \mathrm{m} \mathrm{m}^{-2} \mathrm{~s}^{-1}$, and the cultures grew from an initial cell density of $10^{3}$ cell $\mathrm{ml}^{-1}$ (about $1 \mathrm{ml}$ of a seven-day culture was inoculated into $50 \mathrm{ml}$ medium in $125 \mathrm{ml}$ Erlenmeyer flasks). The flasks were incubated for 14 days at $23^{\circ} \pm 2^{\circ} \mathrm{C}$, without aeration. In order to compare mixo- and autotrophic growth and to discover if heterotrophic growth occurs in this strain, cultures with addition of sodium acetate were established in darkness under the same previously described conditions. The $\mathrm{pH}$ of all treatments was measured after inoculating the alga and adjusting it to a value of 6.0 every three days. Cell density and algal dry weight were determined as growth indices at the end of the experiment.

\section{INDUCTION OF ASTAXANTHIN SYNTHESIS}

\section{a) By nitrogen deprivation and by exposure to high PFD}

When the experiments to determine the best nitrogen source for growth were finished (15 days) and the aliquots for algal dry weight $(20 \mathrm{ml})$ and cell density $(3 \mathrm{ml})$ removed, the cultures with the best growth (in sodium nitrate and ammonium chloride with $\mathrm{pH}$ adjusted during growth between 5.0 - 6.0 range, both grown at the two PFD) were mixed in single cultures: four cultures, corresponding to the two nitrogen sources and the two PFD, were obtained. The volume of each of these cultures was uniformly distributed into eight tubes (each with $20 \mathrm{ml}$ ); four of them were kept at higher PFD $\left(150 \mu \mathrm{mol} \mathrm{m}^{-2} \mathrm{~s}^{-1}\right)$ than during growth $\left(35 \mu \mathrm{mol} \mathrm{m}^{-2} \mathrm{~s}^{-1}\right)$, and the remaining 
four tubes were assayed for nitrogen deprivation. This was achieved by successive centrifugation (three times at $1500 \mathrm{rpm}$ for five min) and re-suspension of the algal pellet in fresh $\mathrm{NaNO}_{3}$-deprived Bristol medium (with isosmotic exchange of $\mathrm{NaNO}_{3}$ by $\mathrm{KCl}$ ). The induction period for all the cultures lasted 12 days. Total carotenoids and chlorophyll "a" content and the relative number of cysts after the induction period were estimated in each replica.

\section{b) By salt stress}

Initially, the alga was cultured in three bottles of five-liter capacity for 11 days with three liters of medium reaching a mean cell density of $1.6 \times 10^{5}$ cells $\mathrm{ml}^{-1}$. Unlike the previous experiments of this study, the inoculum for these cultures consisted of $98 \%$ cysts, and it was taken from a twomonth-old culture at a stationary phase of growth. The bottles were maintained at $19^{\circ} \pm 2^{\circ} \mathrm{C}$, under a continuous PFD of 35 $\mu \mathrm{mol} \mathrm{m} \mathrm{m}^{-2} \mathrm{~s}^{-1}$ (supplied by cool white fluorescent tubes) and continuous aeration given with air filtered through Millipore filters of $0.2 \mu \mathrm{m}$ pore size. The experimental procedure was as following: from bottle $\mathrm{N}^{\circ} 1$ and $\mathrm{N}^{\circ} 2$, volumes of $200 \mathrm{ml}$ of the algal suspension were transferred into $500 \mathrm{ml}$ Erlenmeyer flasks and cultured with $0.0 \%$, $0.2 \%$ and $0.8 \% \mathrm{NaCl}$ at 85 and $35 \mu \mathrm{mol} \mathrm{m}^{-2} \mathrm{~s}^{-}$ ${ }^{1}$, respectively, in triplicate. In order to study the effect of a higher PFD (than that utilized during growth) and the natural aging of the cultures, one set of three flasks (from bottle $\mathrm{N}^{\mathrm{o}} 3$ ) was kept at $150 \mu \mathrm{mol} \mathrm{m} \mathrm{m}^{-2} \mathrm{~s}^{-1}$ without addition of salt. The 21 flasks were incubated at $19^{\circ} \pm 2^{\circ} \mathrm{C}$ without aeration and manually shaken twice a day. At the end, both the growth period (day 11) and the carotenogenesis induction period (day 20, induction period of nine days), algal dry weight and total pigment content (total carotenoids and chlorophyll "a") were determined in $25 \mathrm{ml}$ and $10 \mathrm{ml}$ filtered aliquots, respectively. The total astaxanthin contents, both on a volumetric and on cell dry weight basis, were determined by HPLC analysis.

\section{Analytical Methods}

Growth rate was determined by cell counting using $1 \mathrm{ml}$ Utermohl chambers and a Zeiss inverted microscope, according to Guillard (1973).

Raw extracts of pigments were obtained by grinding the algal cell pellet, utilizing either a manual tissue homogenizer (for vegetative cells) or liquid nitrogen in a mortar (for cysts). Then, the pigments were extracted with $90 \%$ acetone and left overnight at $4^{\circ} \mathrm{C}$ in darkness. The extracts were centrifuged and analyzed by spectrophotometry, according to Strickland and Parsons (1973). The total carotenoid concentrations calculated by this method (at $480 \mathrm{~nm}$ ) are equivalent to using the extinction coefficient $E_{1 \mathrm{~cm}}^{1 \%}=2500$ (Davies, 1976). The total chlorophyll concentration was calibrated as chlorophyll "a" for the major chlorophyll component.

Astaxanthin analysis was carried out by HPLC using equipment with automatic injector pumps, UV variable detector, reverse-phase column RP-18 Lichrocart 250-4 and integrator. Pigments were eluted at a flux rate of $0.5 \mathrm{ml} / \mathrm{min}$, with a solvent system of acetonitrile-dichloromethanemethanol in the proportion 70:20:10 v/v at environmental temperature. Astaxanthin was detected at $480 \mathrm{~nm}$ and was identified by its retention time and absorption spectra with standard substance (Sigma).

\section{Anaerobic saponification of astaxanthin} esters

The esters were dissolved in $\mathrm{CH}_{2} \mathrm{Cl}_{2}$ and $1 \% \mathrm{KOH}$ in $\mathrm{CH}_{3} \mathrm{OH}$ was added under $\mathrm{N}_{2}$. After hydrolysis, the solution was neutralized with $1 \%$ aq. $\mathrm{NH}_{4} \mathrm{Cl}$, and astaxanthin extracted with diethyl ether (Grung et al., 1992).

\section{Statistical analysis}

The data were subjected to statistical analysis, utilizing a factorial design, performing analysis of variance (ANOVA), analysis of covariance and multiple- 
comparisons tests (Tukey, Scheffe, Fisher's least significant difference method) with the computational program STATISTICA. Differences were considered to be significant at a probability of $5 \%(\mathrm{p} \leq 0.05)$.

\section{RESULTS}

Optimum nitrogen source for growth of $H$. pluvialis strain Steptoe

The best nitrogen source for growth in this strain was clearly the ammonium chloride when the $\mathrm{pH}$ was not permitted to attain values lower than 4.0 (Fig.1). When cultivated in sodium nitrate, the growth parameters, i.e., maximum cell density and cell dry weight, were lower than in ammonium chloride, but clearly higher than in urea, where the growth of the alga was deficient (Table I). In the cultures grown with ammonium, the $\mathrm{pH}$ fluctuations due to the acidification of the medium and the modification of the $\mathrm{pH}$ whenever it reached 4.0-4.5, raising it to 6.0, did not affect the algal growth but, on the contrary, permitted these cultures to exhibit the highest cell densities $\left(2.0 \times 10^{5}\right.$ and $2.5 \times$ $10^{5}$ cells $\left.\mathrm{ml}^{-1}\right)$ and algal dry weights $(228.0$ and $257.5 \mathrm{mg} \mathrm{l}^{-1}$ ) at 35 and $85 \mu \mathrm{mol} \mathrm{m} \mathrm{m}^{-2} \mathrm{~s}^{-1}$, respectively. These values were significantly different $(p \leq 0.05)$ from the biomass values obtained in nitrate (at $85 \mu \mathrm{mol} \mathrm{m}^{-2} \mathrm{~s}^{-1}$ ) and/or in urea at both PFD.

In all the nitrogen sources assayed, the relative number of motile vegetative cells during growth was high $(\geq 85 \%)$ and higher in ammonium (95\%) than in the other sources, a condition that supported very healthy cells, showing a deep green color and a very thin translucent cell wall. Due to the $\mathrm{pH}$ decrease in ammonium, which needed a strict modification during growth, in the subsequent experiments of this study sodium nitrate was used as the nitrogen source for growth.

\section{Mixotrophic growth with addition of sodium acetate}

The addition of sodium acetate did not produce any increase in growth at either PFD assayed, when compared to the control cultures (grown without acetate) (Table II). Although a slight increase in the maximal cell densities (from $1.6 \times 10^{5}$ to $1.8 \times 10^{5}$ cells ml $\left.^{-1}\right)$ and in the algal dry weight (from 183 to $204 \mathrm{mg} \mathrm{l}^{-1}$ ) occurred at increasing acetate concentrations at $85 \mu \mathrm{mol}$ $\mathrm{m}^{-2} \mathrm{~s}^{-1}$, the values were not significantly different $(\mathrm{p} \leq 0.05)$ from those obtained in the autotrophic condition. At $35 \mu \mathrm{mol} \mathrm{m} \mathrm{m}^{-2} \mathrm{~s}^{-1}$, the inverse occurred, i.e., the strain grew slower than in the control cultures, and there was a decrease in growth at higher acetate concentration, from $0.43 \mathrm{div}^{-1 a y^{-1}}(4.0 \mathrm{mM})$ to $0.21 \mathrm{div}$ day $^{-1}(12.0 \mathrm{mM})$. Maximal cell densities and dry weight at $12.0 \mathrm{mM}$ acetate $\left(2.5 \times 10^{4}\right.$ cells $\left.\mathrm{ml}^{-1}, 29 \mathrm{mg} \mathrm{l}^{-1}\right)$ were lower by one order of magnitude than the densities and dry weights achieved in the control $\left(2.5 \times 10^{5}\right.$ cells $\mathrm{ml}^{-1}, 298 \mathrm{mg} \mathrm{l}^{-1}$ ). The differences in biomass obtained in the range of acetate concentration at this PFD $\left(35 \mu \mathrm{mol} \mathrm{m} \mathrm{m}^{-2} \mathrm{~s}^{-1}\right)$ were significantly different $(\mathrm{p} \leq 0.05)$ from each other and compared to the control cultures without acetate. On the other hand, the addition of acetate caused a significant increase in the relative amount of cysts, from $0.42 \%$ (control cultures) to $8.7 \%$ (12 $\mathrm{mM}$ acetate) at $35 \mu \mathrm{mol}$ $\mathrm{m}^{-2} \mathrm{~s}^{-1}(\mathrm{p} \leq 0.05)$. A minor increase of cysts was found at $85 \mu \mathrm{mol} \mathrm{m}^{-2} \mathrm{~s}^{-1}$, ranging from $1.9 \%$ in

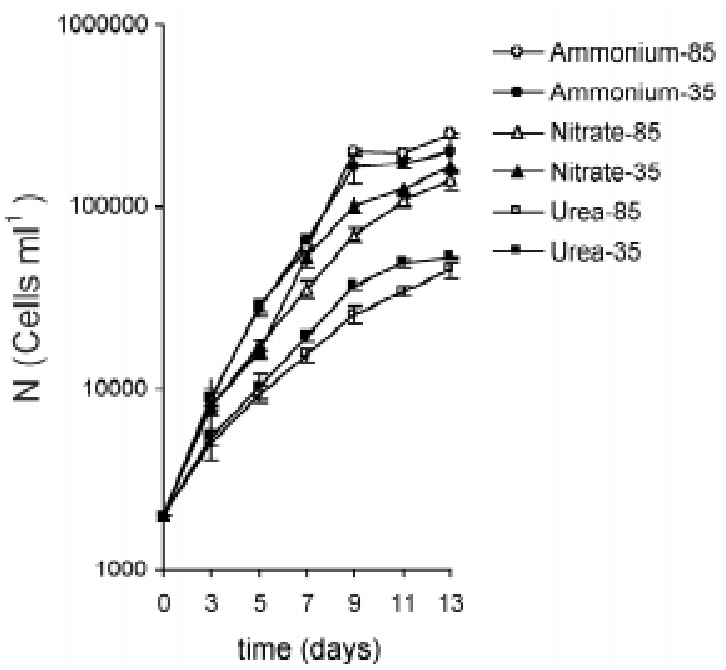

Figure 1: Growth of Haematococcus pluvialis (Steptoe strain) with different nitrogen sources (sodium nitrate, ammonium chloride and urea) and under different photon flux densities ( 35 and $85 \mu \mathrm{mol} \mathrm{m}^{-2} \mathrm{~s}^{-1}$ ), without aeration. 
control cultures to $3.0 \%$ in $12 \mathrm{mM}$ acetate. In darkness, cell density showed no change during the 11 days growth period, but the relative number of cysts increased to $13.9 \%$. Although the $\mathrm{pH}$ was fixed to a value of 6.0 every three days, the variations of this parameter differed just slightly among the different acetate concentrations.

\section{INDUCTION OF ASTAXANTHIN SYNTHESIS}

\section{a) By nitrogen deprivation and by exposure to high PFD}

The best inductive factor for carotenoid accumulation, both per volume and per cell, was exposure to high PFD $\left(150 \mu \mathrm{mol} \mathrm{m}^{-2} \mathrm{~s}^{-1}\right)$ in those cultures pre-grown in nitrate under $35 \mu \mathrm{mol} \mathrm{m} \mathrm{m}^{-2} \mathrm{~s}^{-1}$. By contrast, nitrogen deprivation in the nitrate grown cultures did not produce any increment in total carotenoids, at any of the PFD assayed (Table III).

The carotenoid content in cultures grown in nitrate at $35 \mu \mathrm{mol} \mathrm{m} \mathrm{m}^{-2} \mathrm{~s}^{-1}$ and subjected to high light $\left(150 \mu \mathrm{mol} \mathrm{m}^{-2} \mathrm{~s}^{-1}\right)$ increased from 1.7 to $4.88 \mathrm{mg} \mathrm{l}^{-1}$ and from 10 to $25 \mathrm{pg} \mathrm{cell}^{-1}$, a highly significant increment $(\mathrm{p} \leq 0.05)$ when compared to the increment in carotenoid content obtained under all other treatments. The carotenoid content in cultures grown in nitrate at $85 \mu \mathrm{mol} \mathrm{m} \mathrm{m}^{-2} \mathrm{~s}^{-1}$ and subjected to high light increased much less, both per volume unit (from 2.0 to $2.9 \mathrm{mg}$ $\mathrm{l}^{-1}$ ) and per cell ( from 15 to $17.9 \mathrm{pg} \mathrm{cell}^{-1}$ ), and the final carotenoid content per volume unit was not significantly different ( $\mathrm{p} \leq$ 0.05 ) from the carotenoid accumulated by the cultures grown in ammonium and subjected to N-deprivation (Table III).

The cultures grown in ammonium, where the maximal cell number was two fold higher compared to the cultures grown in nitrate, did not survive in the high PFD treatment (without $\mathrm{pH}$ control) and cells died on day four of the induction period. On the contrary, nitrogen deprivation produced an increment in total carotenoids by a factor 1.6 and 1.4 in cultures grown in ammonium under $85 \mu \mathrm{mol} \mathrm{m}{ }^{-2} \mathrm{~s}^{-1}(3.20 \mathrm{mg}$ $\left.\mathrm{l}^{-1}\right)$ and $35 \mu \mathrm{mol} \mathrm{m} \mathrm{m}^{-2} \mathrm{~s}^{-1}\left(2.85 \mathrm{mg} \mathrm{l}^{-1}\right)$, respectively. This last increment in total carotenoids was very similar to that observed in the cultures grown in nitrate under $85 \mu \mathrm{mol} \mathrm{m}^{-2} \mathrm{~s}^{-1}$ and subjected to high PFD (from $2.0 \mathrm{mg} \mathrm{l}^{-1}$ to $2.9 \mathrm{mg} \mathrm{l}^{-1}$ ).

The total carotenoid content (per liter and per cell) obtained in the $\mathrm{N}$-deprived cells grown in ammonium at 35 and/or 85

TABLE I

Maximum cell density $\left(\mathrm{N}_{\max }\right)$, exponential growth rate $\left(\mathrm{t} \leq 7\right.$ days) $\left(\mathrm{k}_{\max }\right)$, mean growth rate

$(\mathrm{t}=13$ days $)\left(\mathrm{k}_{\text {mean }}\right)$, cell dry weight per volume unit $\left(\mathrm{mg} \mathrm{l}^{-1}\right)$ and per cell $\left(\mathrm{pg} \mathrm{cell}^{-1}\right)$, and relative number of motile vegetative cells and cysts in $H$. pluvialis cultures grown in Bristol medium with different nitrogen sources under two continuous PFD (35 and $85 \mu \mathrm{mol} \mathrm{m}^{-2} \mathrm{~s}^{-1}$ ), temperature of $23^{\circ} \pm 2^{\circ} \mathrm{C}$, without aeration and manually shaken twice a day, for 13 days, from $\mathrm{Ni}=2 \times 10^{3}$ cells $\mathrm{ml}^{-1}$ and $\mathrm{pH}_{\mathrm{i}}=6.0$. (Values are the means of three replicates)

\begin{tabular}{|c|c|c|c|c|c|c|c|}
\hline \multirow[t]{3}{*}{ Parameter } & \multirow{3}{*}{$\begin{array}{l}\text { A } \\
\text { B }\end{array}$} & \multicolumn{6}{|c|}{ Nitrogen source (A) and PFD (B) $\left(\mu \mathrm{mol} \mathrm{m}^{-2} \mathrm{~s}^{-1}\right)$} \\
\hline & & \multicolumn{2}{|c|}{$\mathrm{NH}_{4} \mathrm{Cl}$} & \multicolumn{2}{|c|}{$\mathrm{NaNO}_{3}$} & \multicolumn{2}{|c|}{ Urea } \\
\hline & & 35 & 85 & 35 & 85 & 35 & 85 \\
\hline \multicolumn{2}{|l|}{$\mathrm{N}_{\max }($ cells ml-1) } & $2.0 \times 10^{5}$ & $2.5 \times 10^{5}$ & $1.7 \times 10^{5}$ & $1.4 \times 10^{5}$ & $5.2 \times 10^{4}$ & $4.5 \times 10^{4}$ \\
\hline \multicolumn{2}{|l|}{$\mathrm{k}_{\max }\left(\operatorname{div}\right.$ day $\left.^{-1}\right)$} & 0.72 & 0.70 & 0.68 & 0.59 & 0.47 & 0.44 \\
\hline \multicolumn{2}{|l|}{$\mathrm{k}_{\text {mean }}\left(\operatorname{div}\right.$ day $\left.^{-1}\right)$} & 0.51 & 0.53 & 0.49 & 0.47 & 0.36 & 0.34 \\
\hline \multicolumn{2}{|l|}{ Dry weight per } & 228.0 & 257.5 & 194.3 & 170.0 & 56.0 & 42.0 \\
\hline \multicolumn{8}{|l|}{ volume unit $\left(\mathrm{mg} \mathrm{l}^{-1}\right)$} \\
\hline \multicolumn{2}{|l|}{ Dry weight per cell } & 1140 & 1030 & 1143 & 1210 & 1077 & 933 \\
\hline \multicolumn{8}{|l|}{$\left(\mathrm{pg} \mathrm{cell}^{-1}\right)$} \\
\hline \multicolumn{2}{|l|}{ Final pH } & 3.4 & 3.5 & 7.7 & 7.8 & 6.6 & 6.8 \\
\hline \multicolumn{2}{|l|}{$\%$ motile cells } & 95 & 94 & 90 & 89 & 88 & 85 \\
\hline \multicolumn{2}{|l|}{$\%$ cysts } & 4.6 & 5.8 & 5.0 & 6.6 & 4.9 & 5.5 \\
\hline
\end{tabular}


$\mu \mathrm{mol} \mathrm{m} \mathrm{m}^{-2} \mathrm{~s}^{-1}$ was not significantly different $(\mathrm{p} \leq 0.05)$ from the contents exhibited by $\mathrm{N}$ deprived cells cultivated in nitrate at either PFD (Table III).

The chlorophyll content was much higher in the cultures grown in ammonium than in nitrate under both PFD (2.3 and $1.6 \mathrm{mg} \mathrm{l}^{-1}$ versus 0.9 and $0.7 \mathrm{mg}^{-1}$ under 35 and 85 $\mu \mathrm{mol} \mathrm{m}{ }^{-2} \mathrm{~s}^{-1}$, respectively), and this content remained high in those cultures that survived the carotenogenesis period promoted by nitrogen deprivation $(3.5 \mathrm{mg}$ $\mathrm{1}^{-1}$ and $4.0 \mathrm{mg} \mathrm{l}^{-1}$, under 35 and $85 \mu \mathrm{mol}$ $\mathrm{m}^{-2} \mathrm{~s}^{-1}$, respectively). The carotenoid to chlorophyll ratio was always less than 1 , even before the induction period.

The relative number of cysts was very similar in all growth conditions at the beginning of the carotenogenesis induction period $(4.4 \%-5.8 \%)$, but at the end it was much higher in those cultures induced by high PFD ( $c a .33 \%$ ) than under nitrogen deprivation $(12.8 \%-18.5 \%$ in ammonium and nitrate, both under $85 \mu \mathrm{mol} \mathrm{m} \mathrm{m}^{-2} \mathrm{~s}^{-1}$, respectively).

\section{b) By salt stress}

The results obtained after stressing the cells by addition of salt showed a significant cellular mortality $(\mathrm{p} \leq 0.05)$, being the greatest at the highest salt concentration (45\% cell loss at $0.8 \% \mathrm{NaCl}$ under both PFD) (Table IV). On the contrary, an increase both in cell density and in algal dry weight, in the assays without $\mathrm{NaCl}$, occurred at the three given PFD. This meant that these cultures continue growing as during the experimental inductive period. A significant value $(\mathrm{p} \leq 0.05)$ for the highest algal yield (dry weight and cell density) was obtained at the highest PFD $\left(150 \mu \mathrm{mol} \mathrm{m}^{-2} \mathrm{~s}^{-1}\right)$ without $\mathrm{NaCl}$ (208 $\mathrm{mg} \mathrm{l}^{-1}, 1.8 \times 10^{5}$ cells $\mathrm{ml}^{-1}$ ). Although there was an increment in the total carotenoid content, both per volume and per cell unit (and a concomitant decrease in the chlorophyll content) at increasing salinity under both PFD assayed, the values obtained were considered very low. The best carotenogenic condition by addition of salt was obtained at $85 \mu \mathrm{mol} \mathrm{m} \mathrm{m}^{-2} \mathrm{~s}^{-1}$ with $0.8 \%$ $\mathrm{NaCl}$, raising the total carotenoids per volume unit by a factor of 2.8 with respect to the initial value. In absolute total carotenoid content, cells accumulated $1.72 \mathrm{mg} \mathrm{l}^{-1}$ and $22 \mathrm{pg} \mathrm{cell}^{-1}$ with a carotenoid to chlorophyll ratio of 4.2 . The increment in total carotenoids produced in this condition was significantly different from the increments estimated in the other conditions, except for the increments observed at $85 \mu \mathrm{mol} \mathrm{m} \mathrm{m}^{-2} \mathrm{~s}^{-1}$

TABLE II

Growth $\left(\mathrm{N}_{\text {cells ml }}{ }^{-1}\right.$ and $\left.\mathrm{k}_{\text {div day }}{ }^{-1}\right)$ and algal dry weight (a.d.w. $\left.{ }_{\mathrm{mg} 1}^{-1}\right)$ of H. pluvialis cultured during 11 days (from $\mathrm{Ni}=5 \times 10^{3}$ cells $\mathrm{ml}^{-1}$ ), in Bristol medium with addition of sodium acetate $\left(4,8\right.$ and $12 \mathrm{mM}$ ) and under two PFD (35 and $\left.85 \mu \mathrm{mol} \mathrm{m}^{-2} \mathrm{~s}^{-1}\right)$. Controls in autotrophic and heterotrophic growth were kept without addition of acetate under the two PFD and with $12 \mathrm{mM}$ acetate in darkness, respectively. The relative amount of cysts (\%) at the end of the growth period was also determined. (Values are the means of three replicates)

\begin{tabular}{l|c|c|c|c|c|c|c|c|c}
\hline & \multicolumn{4}{|c|}{$35 \mu \mathrm{mol} \mathrm{m}^{-2} \mathrm{~s}^{-1}$} & \multicolumn{3}{c}{$85 \mu \mathrm{mol} \mathrm{m}^{-2} \mathrm{~s}^{-1}$} & \multicolumn{2}{c}{ darkness } \\
\hline $\begin{array}{l}\text { sodium acetate } \\
\text { concentration (mM) }\end{array}$ & $\begin{array}{c}\text { without sodium } \\
\text { acetate }\end{array}$ & 4.0 & 8.0 & 12.0 & $\begin{array}{c}\text { without sodium } \\
\text { acetate }\end{array}$ & 4.0 & 8.0 & 12.0 & 12.0 \\
\hline $\mathrm{pH}$ variation & $6.0-6.85$ & $6.0-7.09$ & $6.0-8.00$ & $6.0-8.42$ & $6.0-6.78$ & $6.0-7.50$ & $6.0-8.42$ & $6.0-8.73$ & $6.0-8.42$ \\
\hline $\mathrm{N}_{\text {cells ml }}{ }^{-1}$ & $2.5 \times 10^{5}$ & $1.4 \times 10^{5}$ & $9.7 \times 10^{4}$ & $2.5 \times 10^{4}$ & $1.5 \times 10^{5}$ & $1.6 \times 10^{5}$ & $1.7 \times 10^{5}$ & $1.8 \times 10^{5}$ & $5.1 \times 10^{3}$ \\
\hline $\mathrm{k}_{\text {div day }}{ }^{-1}$ & 0.42 & 1.02 & 1.3 & 8.7 & 1.9 & 2.6 & 2.3 & 3.0 & 13.9 \\
\hline a.d.w. $\mathrm{mg} 1^{-1}$ & 0.51 & 0.43 & 0.39 & 0.21 & 0.45 & 0.45 & 0.46 & 0.47 & 0.0014 \\
\hline
\end{tabular}


Algal dry weight (a.d.w. $\left.{ }_{\mathrm{mg}}{ }^{-1}\right)$, total carotenoid content per volume ( $\left.\mathrm{car}_{\mathrm{mg} 1}{ }^{-1}\right)$, on a dry weight basis ( car $\left._{\mathrm{mg} \mathrm{g}}{ }^{-1}\right)$, per cell (car ${ }_{\mathrm{pg} \text { cell }}^{-1}$ ), chlorophyll "a" (chl “a”) per volume unit (chl "a" $\left.{ }_{\mathrm{mg}}^{-1}\right)$, cell density ( $\mathrm{N}_{\text {cells ml }}^{-1}$ ), color of extract and relative number $(\%)$ of cysts in H. pluvialis cultured in $\mathrm{NaNO}_{3}$ and $\mathrm{NH}_{4} \mathrm{Cl}$, under two PFD (35 y $85 \mu \mathrm{mol} \mathrm{m}^{-2} \mathrm{~s}^{-1}$ ) and then subjected to carotenogenesis induction by nitrogen deprivation and by exposure to high PFD (150 $\mu \mathrm{mol} \mathrm{m}^{-2}$ $\mathrm{s}^{-1}$ ) for 12 days. (Values are the means of three replicates ( $\mathrm{B}=$ before and $\mathrm{A}=$ after induction); n.d.=not determined because of culture death)

\begin{tabular}{|c|c|c|c|c|c|c|c|c|c|}
\hline & & \multicolumn{2}{|c|}{$\mathrm{NaNO}_{3}$} & \multicolumn{2}{|c|}{$\mathrm{NaNO}_{3} \quad(85)$} & \multicolumn{2}{|c|}{$\mathrm{NH}_{4} \mathrm{Cl}$} & \multicolumn{2}{|c|}{$\mathrm{NH}_{4} \mathrm{Cl}$} \\
\hline & & $-\mathrm{N}$ & high PFD & $-\mathrm{N}$ & high PFD & $-\mathrm{N}$ & high PFD & $-\mathrm{N}$ & high PFD \\
\hline \multirow[t]{2}{*}{ a.d.w.mg $1^{-1}$} & $\mathrm{~B}$ & \multicolumn{2}{|c|}{194.0} & \multicolumn{2}{|c|}{170.0} & \multicolumn{2}{|c|}{228.0} & \multicolumn{2}{|c|}{258.0} \\
\hline & $\mathrm{A}$ & 173.0 & 237.0 & 209.0 & 190.0 & 279.0 & n.d. & 315.0 & n.d. \\
\hline \multirow{2}{*}{$\mathrm{car}_{\mathrm{mg}} 1^{-1}$} & $\mathrm{~B}$ & \multicolumn{2}{|c|}{1.70} & \multicolumn{2}{|c|}{2.04} & \multicolumn{2}{|c|}{1.98} & \multicolumn{2}{|c|}{2.06} \\
\hline & A & 1.84 & 4.88 & 1.91 & 2.87 & 2.85 & n.d. & 3.19 & n.d. \\
\hline \multirow{2}{*}{$\mathrm{car}_{\mathrm{mg} \mathrm{g}}^{-1}$} & B & \multicolumn{2}{|c|}{8.8} & \multicolumn{2}{|c|}{12.0} & \multicolumn{2}{|c|}{8.7} & \multicolumn{2}{|c|}{8.0} \\
\hline & A & 10.6 & 20.6 & 9.14 & 15.1 & 10.2 & n.d. & 10.1 & n.d. \\
\hline \multirow[t]{2}{*}{ chl "a" ${ }_{\mathrm{mgl}}{ }^{-1}$} & B & \multicolumn{2}{|c|}{0.87} & \multicolumn{2}{|c|}{0.65} & \multicolumn{2}{|c|}{2.33} & \multicolumn{2}{|c|}{1.64} \\
\hline & A & 1.41 & 1.09 & 1.06 & 0.59 & 3.53 & n.d. & 4.05 & n.d. \\
\hline \multirow[t]{2}{*}{ car chl-1 } & B & \multicolumn{2}{|c|}{1.97} & \multicolumn{2}{|c|}{3.21} & \multicolumn{2}{|c|}{0.92} & \multicolumn{2}{|c|}{1.43} \\
\hline & A & 1.30 & 4.60 & 1.80 & 5.12 & 0.82 & n.d. & 0.80 & n.d. \\
\hline \multirow{2}{*}{ car $_{p g}$ cell $^{-1}$} & B & \multicolumn{2}{|c|}{10.0} & \multicolumn{2}{|c|}{15.0} & \multicolumn{2}{|c|}{10.0} & \multicolumn{2}{|c|}{8.0} \\
\hline & $\mathrm{A}$ & 12.2 & 25.0 & 10.6 & 17.9 & 11.4 & n.d. & 10.3 & n.d. \\
\hline $\mathrm{N}_{\text {cells ml }}{ }^{-1}$ & $\mathrm{~B}$ & & & & & & & & \\
\hline & $\mathrm{A}$ & $1.5 \times 10^{5}$ & $1.95 \times 10^{5}$ & $1.8 \times 10^{5}$ & $1.6 \times 10^{5}$ & $2.5 \times 10^{5}$ & n.d. & $3.1 \times 10^{5}$ & n.d. \\
\hline color of extract & B & slight y & -orange & bright & -orange & greenis & yellow & & \\
\hline & A & $\begin{array}{c}\text { Bright } \\
\text { orange-green }\end{array}$ & $\begin{array}{c}\text { bright } \\
\text { orange-red }\end{array}$ & $\begin{array}{l}\text { slight } \\
\text { orange }\end{array}$ & $\begin{array}{c}\text { slight } \\
\text { orange-red }\end{array}$ & $\begin{array}{l}\text { grass- } \\
\text { green }\end{array}$ & colorless & $\begin{array}{l}\text { grass- } \\
\text { green }\end{array}$ & colorless \\
\hline$\%$ cysts & $\mathrm{B}$ & & & & & & & & \\
\hline & A & 15,4 & 33,6 & 18,5 & 33,3 & 3,8 & n.d. & 12,8 & n.d. \\
\hline
\end{tabular}

without $\mathrm{NaCl}$ and at $85 \mu \mathrm{mol} \mathrm{m} \mathrm{m}^{-2} \mathrm{~s}^{-1}$ with $0.2 \% \mathrm{NaCl}(\mathrm{p} \leq 0.05)$, in which the carotenoid content increased by a factor of 2.6 and 2.7 , respectively. Under $35 \mu \mathrm{mol} \mathrm{m}^{-2} \mathrm{~s}^{-1}$ and with $0.8 \% \mathrm{NaCl}$, the total carotenoid content increased less (by a factor of 1.3 and 2.3, for carotenoids per volume and per cell, respectively). The carotenoid to chlorophyll ratio in this condition was almost two fold higher than that estimated before the addition of salt (it varied from 0.8 to 1.5 ).

In relation to astaxanthin content, the highest amounts were obtained without $\mathrm{NaCl}$ under 85 and $150 \mu \mathrm{mol} \mathrm{m} \mathrm{m}^{-2} \mathrm{~s}^{-1}: 1.07$ and $0.77 \mathrm{mg} \mathrm{l}^{-1}$, respectively, corresponding to $68 \%$ and $44 \%$ of the total carotenoids estimated by spectrophotometry. The maximum astaxanthin content per dry weight, $10.25 \mathrm{mg} \mathrm{g}^{-1}(1.0 \% \mathrm{w} / \mathrm{w})$, was registered under $85 \mu \mathrm{mol} \mathrm{m} \mathrm{m}^{-2} \mathrm{~s}^{-1}$ with $0.8 \%$ $\mathrm{NaCl}$, and it was significantly different from all other treatments $(\mathrm{p} \leq 0.05)$.

\section{DISCUSSION}

The culture of H. pluvialis, both in laboratory conditions and for commercial purposes, has received much attention, even though research on the factors controlling growth and astaxanthin accumulation have yielded controversial results, postponing the management of the cause-effect association within reliable certitude. In part, this lack 
of conclusive results has discouraged research on the scale-up of astaxanthin production, unlike the culture of Dunaliella (for $\beta$-carotene production), which is successfully carried out in many countries. To a certain extent, this has been due to the complex life cycle of this microalga, which exhibits different morphological cell types -macrozooids, microzooids, aplanospores, "palmella" stages and cysts (Elliot, 1934; Santos and Mesquita, 1984)- and to a poor understanding of the optimal conditions for growth and astaxanthin accumulation of any of these morphological cell types. Moreover, the great variations in experimental designs, culture conditions and strains utilized, make the comparison of the data almost impossible.

In the strain under study (Steptoe), carotenoid accumulation occurs both in motile and resting cells, but in batch culture conditions our group has observed that the vegetative cells prevail irremediably for a definite short period of time, and non-motile cells begin to predominate with the evolution of the culture. According to Lee and Ding (1994) studying the strain UTEX 16, this evidence would correspond to an increase in cell number of five cell doublings, irrespective of the magnitude in growth rate, with a concomitant increase in the number of non-motile cells until motile cells disappear from the culture after about twelve days. Spherical non-motile cells ("palmella" stage) are capable of undergoing asexual reproduction, releasing a variable number of motile or non-motile cells. In the Steptoe strain, and in accordance with the observations of Lee and Ding (1995), only in old cultures is it possible to observe resting stages (or cysts or true resting akinetes) with thick walls. Our primary interest, therefore, was to define conditions to support optimal vegetative growth and subsequent carotenogenesis by inductive factors recognized in the literature.

\section{TABLE IV}

Algal dry weight, maximum cell density $(\mathrm{Nmax})$, growth rate $(\mathrm{t}=5)\left(\mathrm{k}_{\max }\right)$, total carotenoids content (car) and chlorophyll "a" (chl "a") per volume and per cell, carotenoids to chlorophyll

"a" ratio (car/chl "a"), and total astaxanthin at the end of the growth period (day 11) in cultures of $H$. pluvialis before (B) and after (A) the carotenogenesis induction by addition of $\mathrm{NaCl}$ or by exposal to high PFD $\left(150 \mathrm{~mol} \mathrm{~m}^{-2} \mathrm{~s}^{-1}\right.$, without $\left.\mathrm{NaCl}\right)$. Data are the means of three replicates.

\begin{tabular}{|c|c|c|c|c|c|c|c|c|c|c|c|c|}
\hline Vial & $\begin{array}{c}\text { PFD } \\
\mu \mathrm{mol} \mathrm{m} \mathrm{m}^{-2} \mathrm{~s}^{-1}\end{array}$ & $\begin{array}{l}\text { Treatment } \\
(\% \mathrm{NaCl})\end{array}$ & & $\begin{array}{c}\text { Algal dry } \\
\text { weight } \\
\left(\mathrm{mg} \mathrm{l}^{-1}\right)\end{array}$ & $\begin{array}{c}\mathrm{Nmax} \\
\left(\text { cells } \mathrm{ml}^{-1}\right)\end{array}$ & $\begin{array}{l}\mathrm{k}_{\text {máx }} \\
(\mathrm{t}=5)\end{array}$ & $\begin{array}{c}\text { Total car } \\
\left(\mathrm{mg} \mathrm{l}^{-1}\right)\end{array}$ & $\begin{array}{l}\text { chl "a" } \\
\left(\mathrm{mg} \mathrm{l}^{-1}\right)\end{array}$ & $\begin{array}{c}\mathrm{Car} / \mathrm{chl} \\
\text { "a" } \\
\left(\mathrm{g} \mathrm{g}^{-1}\right)\end{array}$ & $\begin{array}{l}\text { Total car } \\
\left(\mathrm{pg} \text { cél}^{-1}\right)\end{array}$ & $\begin{array}{c}\text { Total } \\
\text { astaxanthin } \\
\left(\mathrm{mg} \mathrm{l}^{-1}\right)\end{array}$ & $\begin{array}{c}\text { Total } \\
\text { astaxanthin } \\
\text { (mg g-1 dry } \\
\text { weight })\end{array}$ \\
\hline \multirow[t]{2}{*}{1} & \multirow[t]{2}{*}{150} & \multirow[b]{2}{*}{0} & B & 128 & $1.4 \times 10^{5}$ & 0.98 & 0.77 & 0.74 & 1.0 & 4.5 & 0.144 & 1.1 \\
\hline & & & A & 208 & $1.8 \times 10^{5}$ & & 1.76 & 0.37 & 4.7 & 10.3 & 0.765 & 3.7 \\
\hline \multirow{4}{*}{2} & \multirow{4}{*}{35} & & B & 144 & $1.4 \times 10^{5}$ & 0.94 & 0.69 & 0.82 & 0.8 & 5.7 & 0.185 & 1.3 \\
\hline & & 0 & \multirow{3}{*}{ A } & 175 & $1.6 \times 10^{5}$ & & 0.95 & 0.81 & 1.2 & 6.4 & 0.431 & 2.5 \\
\hline & & 0.2 & & 123 & $1.1 \times 10^{5}$ & & 0.82 & 0.73 & 1.1 & 7.5 & 0.433 & 3.5 \\
\hline & & 0.8 & & 85 & $7.6 \times 10^{4}$ & & 0.90 & 0.60 & 1.5 & 13.1 & 0.349 & 4.1 \\
\hline \multirow{4}{*}{3} & \multirow{4}{*}{85} & & B & 152 & $1.4 \times 10^{5}$ & 0.90 & 0.62 & 0.76 & 0.8 & 4.4 & 0.0726 & 0.5 \\
\hline & & 0 & \multirow{3}{*}{ A } & 185 & $1.7 \times 10^{5}$ & & 1.58 & 0.77 & 2.1 & 9.8 & 1.069 & 5.8 \\
\hline & & 0.2 & & 136 & $1.1 \times 10^{5}$ & & 1.66 & 0.53 & 3.1 & 15.0 & 0.426 & 3.1 \\
\hline & & 0.8 & & 48 & $7.8 \times 10^{4}$ & & 1.72 & 0.41 & 4.2 & 22.0 & 0.492 & 10.3 \\
\hline
\end{tabular}




\section{Optimum N source for growth}

The optimum nitrogen source for growth in the studied strain, ammonium chloride, not only produced a higher biomass (estimated both as cell density and as cell dry weight) when compared to the other $\mathrm{N}$ sources assayed, but also a healthy state of the motile vegetative cells in the culture, evidenced by a deep green color, a large cell size and a thin extracellular matrix. Nevertheless, the strong acidification of the medium, that demanded a rigorous adjustment of the $\mathrm{pH}$ during growth, discouraged the use of this $\mathrm{N}$ source in the successive growth experiments due to practical considerations $(\mathrm{pH}$ could not be strictly monitored and adjusted in cultures of higher volume).

As early as 1950 s, Proctor (1957) found that $\mathrm{N}$-nitrate is preferred to $\mathrm{N}$-ammonium for growth in $H$. pluvialis, and Stross (1963) concluded that nitrate preference in this species is controlled by the strain, age of inoculum and $\mathrm{pH}$ of the medium, so that exponentially-growing cells at acid $\mathrm{pH}$ preferred ammonium for their growth. According to this author, there are strain differences in the mechanism of $\mathrm{N}$ utilization. On the other hand, it should be borne in mind that a high cell concentration of vegetative cells, transferred to an inductive carotenogenic situation, does not always accumulate astaxanthin (Borowitzka et al., 1991). These authors, working with two strains of $H$. pluvialis (MUR-1 and MUR-64, from Switzerland and Finland, respectively) found that although nitrate, ammonium and urea gave similar final cell yields, the best nitrogen source for both growth and carotenoid accumulation was nitrate, since the carotenogenesis was slightly inhibited in the ammonium- and urea-grown cultures. Therefore, growth and carotenogenesis have to be studied together in order to decide the best conditions for pigment production by a particular strain.

Numerous authors have reported cell division rates in growing cultures of $H$. pluvialis under many different conditions, and these rates have varied from 0.2 div day ${ }^{-1}$ in cultures at commercial scale (Olaizola, 2000) to $0.9 \mathrm{div}$ day $^{-1}$ under laboratory conditions (Grünewald et al., 1997; Hagen et al., 2000; Orosa et al., 2001). The growth rates obtained in our study are within these ranges $(0.44$ to 0.72 div day $^{-1}$, Table I). The same occurred with the maximal cell densities that were in the range of 1.0 to $2.5 \times 10^{5}$ cells $\mathrm{ml}^{-1}$, which are considered low, but similar to those found by other authors (Hagen et al., 1993; Lee and Ding 1994, 1995; Harker et al., 1996b; Tripathi et al., 1998).

The different $\mathrm{N}$-sources assayed here were studied at two PFD since an important factor to consider for algal growth is irradiance. Harker et al., (1995) found that vegetative cells of $H$. pluvialis strain CCAP 34/7 required a relatively low irradiance (40 to $50 \mu \mathrm{mol} \mathrm{m} \mathrm{m}^{-2} \mathrm{~s}^{-1}$ ) to achieve high growth rates. Fan et al., (1994) found an optimal irradiance of $90 \mu \mathrm{mol} \mathrm{m}^{-2} \mathrm{~s}^{-1}$, when studying the effect of temperature and light on growth of $H$. pluvialis strain 192.8 (from the Göttingen Culture Collection). The PFD used in our study were selected according to previous qualitative observations on light optimum for growth in the Steptoe strain (prefers low light). This was proven in cultures grown in nitrate in which the Steptoe strain reached higher maximal cell densities at $35 \mu \mathrm{mol} \mathrm{m}^{-2} \mathrm{~s}^{-1}$ than at $85 \mu \mathrm{mol}$ $\mathrm{m}^{-2} \mathrm{~s}^{-1}\left(1.7 \times 10^{5}\right.$ versus $1.4 \times 10^{5}$ cells $\left.\mathrm{ml}^{-1}\right)$.

\section{Mixotrophic growth with addition of sodium acetate}

Since the early 1960s, it has been shown that Haematococcus can be grown mixotrophically on acetate (Droop, 1961; Pringsheim, 1966). The methods assayed here included mixo- and heterotrophic growth, using sodium acetate as the organic carbon source as did other authors (Kobayashi et al., 1991, 1992, 1997b; Borowitzka et al., 1991; Gong and Chen, 1997; Orosa et al., 2001). Although most work has found enhanced grow th rates with acetate and has recommended mixotrophic and heterotrophic cultivation system for commercial application, it is also true that some work has reported slow cell growth and low final cell densities when growth is carried out in batch mode (Borowitzka et 
al., 1991; Tjahjono et al., 1994; Hata et al., 2001). The results obtained with the Steptoe strain discouraged the use of mixotrophic condition, at least under the concentrations and conditions assayed here, since both growth rates and maximum cell densities were only slightly higher than in autotrophic cultures (controls) at $85 \mu \mathrm{mol} \mathrm{m} \mathrm{m}^{-2} \mathrm{~s}^{-1}$. At 35 $\mu \mathrm{mol} \mathrm{m} \mathrm{m}^{-2} \mathrm{~s}^{-1}$ and in darkness, the growth was severely inhibited. This strain might require a modified culture system (i.e., a repeated fed batch cultivation such as the system implemented by Hata et al., 2001) or a very long cultivation time. An additional potential problem with mixotrophic cultivation is contamination by bacteria, which is very difficult to avoid. It is not surprising then that, due to these hindrances, the cultivation of $H$. pluvialis at commercial scale is being carried out under autotrophic condition, and only stock cultures, which are maintained as inocula, are cultured with sodium acetate (Spencer, 1989; Bubrick, 1991).

Since the effect of acetate is influenced by the $\mathrm{pH}$ of the medium (Borowitzka et al., 1991) the $\mathrm{pH}$ was measured and adjusted to a predefined value of 6.0 , every three days. In preliminary assays, the Steptoe strain preferred slightly acid $\mathrm{pH}$ (data not included) and since the concentrated sodium acetate solution used as stock had a $\mathrm{pH}$ of 8.11 , the adjustment in $\mathrm{pH}$ regulated the initial $\mathrm{pH}$ (that varied from 6.0 to 8.7 before adjusting).

On the other hand, the supplementation of acetate induced an increase in the relative number of cysts at both PFD assayed (by a factor of $c a .20$ and 12 in the cultures at 12 $\mathrm{mM}$ acetate under $35 \mu \mathrm{mol} \mathrm{m} \mathrm{m}^{-2} \mathrm{~s}^{-1}$ and 85 $\mu \mathrm{mol} \mathrm{m} \mathrm{m}^{-2} \mathrm{~s}^{-1}$, respectively) which agrees with the results found by various authors (Borowitzka et al., 1991; Kakizono et al., 1992). The latter authors have assayed the supplementation of acetate both to increase the vegetative growth of green cells and to induce the formation of cysts. However, they found that encystment is drastically retarded when acetate was added together with a high concentration of nitrate, which would be an indication that the encystment is triggered by a high $\mathrm{C} / \mathrm{N}$ ratio and not only by a determined acetate concentration.
$N$-deprivation and high PFD in carotenogenesis

Exposure to a nitrogen-deprived medium has been an effective condition for increasing the astaxanthin accumulation in Haematococcus (Boussiba and Vonshak, 1991; Zlotnik et al., 1993; Spencer, 1989; Bubrick, 1991; Hagen et al., 2000; Harker et al., 1995, 1996b). However, in our work, the carotenogenesis induced under this condition was severely inhibited in the cultures pre-grown in ammonium. The same response has been found in $H$. pluvialis by Borowitzka et al. (1991) and Orosa et al. (2001) and in Dunaliella salina by Borowitzka and Borowitzka (1988). These authors concluded, in accordance with our results, that a culture with a high concentration of vegetative cells subjected to an inductive carotenogenic factor will not always be triggered to accumulate astaxanthin; furthermore, a sharp decrease in cell number may occur. They suggest that the shift from optimal growth conditions to inductive carotenogenic condition must occur when most of the cells in the culture are encysted. Although they employed a similar methodology to this study, Hagen et al. (2000) and Zlotnik et al. (1993) reported disparate results: a faster rate of secondary carotenoid biosynthesis in flagellate than in aplanospore cell stages when pre-grown vegetative cells were transferred to a nitrate-deprived medium and increased irradiance. According to these controversial results, it is not clear if the ammonium is the principal factor responsible for inhibited carotenogenesis or the predominant celltype in the cultures. In our study, inhibited or slight carotenogenesis was found both in nitrate and ammonium pre-cultivated cells when they were transferred to a $\mathrm{N}$-deprived medium, although the state of the cells in both $\mathrm{N}$-source cultures at the beginning of the experiments was very different when comparing the total carotenoids to chlorophyll ratios $(2.0$ and 0.9 , at $35 \mu \mathrm{mol}$ $\mathrm{m}^{-2} \mathrm{~s}^{-1} ; 3.2$ and 1.4 , at $85 \mu \mathrm{mol} \mathrm{m} \mathrm{m}^{-2} \mathrm{~s}^{-1}$ in nitrate and ammonium pre-cultivated 
cultures, respectively). Indeed, and according to Orosa et al. (2001), the induction of astaxanthin production is triggered by stress factors that are cumulative of the physiological state of the cells and the culture conditions.

The $\mathrm{N}$-deprivation was ineffective in increasing the amount of secondary carotenoids accumulated by the strain under study. On the other hand, the exposure to

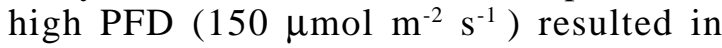
increased carotenogenesis in those cultures pre-cultivated in $\mathrm{N}$-nitrate at both PFD assayed. The same pattern did not occur in the $\mathrm{N}$-ammonium grown cultures under the two PFD, where cells did not survive the experimental period of twelve days. A strong acidification of the medium in these cultures was the cause of the observed cell death. This acidification might have occurred due to continuing growth during the first days of the high light inductive period. Boussiba and Vonshak (1991) have reported that cells subjected to $\mathrm{N}$-deprived medium may support additional growth utilizing an intracellular source of nitrogen when this nutrient has been exhausted in the medium.

The total carotenoid content per volume unit and per cell estimated in this work may be considered low, when compared to data reported in the literature. According to Harker et al. (1996a), the period required by the alga to synthesize significant quantities of astaxanthin is relatively long. These authors found that when $\mathrm{NaCl}$ and high PFD were the inductive factors assayed, all substantial changes in carotenoid content occurred after day 40, and the most significant quantities of pigment were accumulated in the 40- to 90-day period. In the same manner Zlotnik et al. (1993) found high amounts of total carotenoids per cell after four weeks exposure to a nitratedeprived medium. It is noteworthy that these authors observed that the loss of motility took place during the second week under nitrogen depletion. In our experiments, under this condition, by day 12 only $15.4 \%$ of the cells pre-grown in nitrate were immotile and the cultures appeared bright orangegreen in color $\left(\mathrm{car} \mathrm{chl}^{-1}=1.3,12.2 \mathrm{pg} \mathrm{cell}^{-1}\right)$. Very similar carotenoid accumulation per cell occurred in the cultures pre-grown in ammonium (from 10.0 to $11.4 \mathrm{pg} \mathrm{cell}^{-1}$ ), but the high chlorophyll content (car clor $^{-1}=$ 0.82) in these cultures made them appear grass-green in color.

\section{Carotenogenesis by salt stress}

The accumulation of astaxanthin in cysts under salt stress conditions has been reported both in the dark (Kobayashi et al., 1997b) and in the light (Spencer, 1989; Borowitzka et al., 1991; Boussiba and Vonshak, 1991; Boussiba et al., 1992; Cordero et al., 1996; Harker et al., 1995, $1996 \mathrm{a}, \mathrm{b})$. Although the addition of $\mathrm{NaCl}$ in our study was made according to the recommendations of Harker et al. (1996a), the mortality of cells increased substantially with the increase of salt concentration, and only $55 \%$ of cells survived at $0.8 \% \mathrm{NaCl}$ (138 mM); similar mortality data were reported by Harker et al. (1996b) with $0.6 \%$ $\mathrm{NaCl}(103 \mathrm{mM})$. In spite of this high mortality, an increase in red coloration of the surviving cells at higher salinity was evident in our work. An increase in total carotenoid content per cell and in astaxanthin content per dry weight occurred at increasing $\mathrm{NaCl}$ concentrations, and they were the highest when the addition of $\mathrm{NaCl}$ was combined with high PFD $(85 \mu \mathrm{mol}$ $\left.\mathrm{m}^{-2} \mathrm{~s}^{-1}\right)$. These results proved that $\mathrm{NaCl}$ is a carotenogenic inductive factor in this strain, but the methodology employed here requires improvement to be suited to carotenoid production. Harker et al. (1995), studying the effectiveness of the addition of $\mathrm{NaCl}$ on the carotenogenesis of $H$. pluvialis strain CCAP 34/7, improved the final astaxanthin yield when they combined a lower amount of $\mathrm{NaCl}$ than that used here (25-30 mM; $0.14-0.17 \%)$ with exposure to a very high PFD (1600-1700 $\left.\mu \mathrm{mol} \mathrm{m}^{-2} \mathrm{~s}^{-1}\right)$. On the other hand, Sarada et al. (2002) found that the age of the culture was crucial to trigger astaxanthin production in salt stress induced cultures. Younger cultures (four to eight days old) were very sensitive to $\mathrm{NaCl}$ addition, while older cultures (1216 days old) were resistant and accumulated much more astaxanthin when $\mathrm{NaCl}$ was 
added along with sodium acetate and after a prolonged incubation time (20 days).

The levels of carotenoids accumulated by salt stressed cells in this study are low if they are compared to those reported in the literature with the same inductive factor. According to the literature (Harker et al., 1995, 1996a, b; Sarada et al., 2002), $H$. pluvialis would require a longer inductive period than assayed here or a combination of factors for accumulating a high carotenoid content.

The best carotenogenic condition in this work was the high PFD applied to the cultures pre-cultivated with nitrate as $\mathrm{N}$ source and under $35 \mu \mathrm{mol} \mathrm{m}^{-2} \mathrm{~s}^{-1}\left(4.9 \mathrm{mg} \mathrm{l}^{-1}\right.$, $25.0 \mathrm{pg} \mathrm{cell}^{-1}$ ) which is coincident with the results of Harker et al. (1996b). They found that the single most important factor in terms of carotenogenesis was to subject the alga to high PFD, when comparing this effect with nitrate deficiency or other inductive factors. Under salt stress, the maximum yield of total carotenoids (1.7 $\mathrm{mg} 1^{-1}$ ) was low, but the maximum carotenoid content per cell $\left(22.0 \mathrm{pg} \mathrm{cell}^{-1}\right)$ was similar to the content accumulated under the prior condition.

The maximal carotenoid content per unit volume $\left(1.6-1.8 \mathrm{mg} \mathrm{l}^{-1}\right)$ was obtained at $150 \mu \mathrm{mol} \mathrm{m}^{-2} \mathrm{~s}^{-1}$ and $85 \mu \mathrm{mol} \mathrm{m}^{-2} \mathrm{~s}^{-1}$, almost independently of salt concentration, while the highest carotenoid content per cell was obtained at $0.8 \% \mathrm{NaCl}$ and $85 \mu \mathrm{mol} \mathrm{m} \mathrm{m}^{-2} \mathrm{~s}^{-1}$, conditions at which the lowest algal dry weight was found.

In general, the amount of astaxanthin produced by $H$. pluvialis is greater than $0.5 \%$ on a dry weight basis (Spencer, 1989 ; Gong and Chen, 1997; Chaumont and Thèpenier, 1995; Olaizola, 2000) but values from 1.0 - $2.0 \%$ (Spencer, 1989; Cordero et al., 1996; Kobayashi et al., 1991; Hagen et al., 2001; Orosa et al., 2001) or higher (Margalith, 1999; Olaizola, 2000; Lee and Soh, 1991; Bubrick, 1991) have been reported. Assuming that total astaxanthin constitutes at least $60-80 \%$ of total carotenoid content in $H$. pluvialis (Tripathi et al., 1998; Spencer, 1989; Chaumont and Thèpenier, 1995), the total carotenoid accumulation produced in the best condition in the present study, $2.07 \% \mathrm{w} / \mathrm{w}$, would mean an astaxanthin accumulation of 1.2$1.7 \% \mathrm{w} / \mathrm{w}$.

A preliminary estimation of total astaxanthin content made by HPLC in an old stationary culture of this strain (deep red in color), gave a much higher value: $15.9 \mathrm{mg} \mathrm{l}^{-1}$; $3.5 \%$ w/w (Vergara, 2002). Clearly, the management for astaxanthin productivity in this strain can be improved, and new experiments in this regard are in progress.

\section{ACKNOWLEDGMENTS}

We thank Dr. Annette W. Coleman (Brown University, USA) for correcting the manuscript. This research was supported by DIUC grant $\mathrm{N}^{\circ}$ 200.111.023-1.0, University of Concepción, Chile.

\section{REFERENCES}

ARMSTRONG GA (1997) Genetics of eubacterial carotenoid biosynthesis: a colorful tale. Annu Rev Microbiol 51: 629-659

BARBERA E, TOMAS X, MOYA MJ, IBAÑEZ A, MOLINS MB (1993) Significance tests in the study of the specific growth rate of Haematococcus lacustris: influence of carbon source and light intensity. J Ferment Biotech 76: 403-405

BOROWITZKA M, BOROWITZKA L (1988) Micro-algal Biotecnology. Boston: Cambridge University Press. pp: 477

BOROWITZKA MA, HUISMAN JM, OSBORN A (1991) Culture of astaxanthin-producing green alga Haematococcus pluvialis I. Effects of nutrients on growth and cell type. J appl Phycol 3: 295-304

BOUSSIBA S, VONSHAK A (1991) Astaxanthin accumulation in the green alga Haematococcus pluvialis. Plant Cell Physiol 32: 1077-1082

BOUSSIBA S, FAN L, VONSHAK A (1992) Enhancement and determination of astaxanthin accumulation in green alga Haematococcus pluvialis. Methods in Enzymology 213: 386-391

BUBRICK P (1991) Production of astaxanthin from Haematococcus. Bioresource Technology 38: 237-239

CHAUMONT D, THËPENIER C (1995) Carotenoid content in growing cells of Haematococcus pluvialis during a sunlight cycle. J appl Phycol 7: 529-537

CIFUENTES AS, GONZÁLEZ MA, CONEJEROS M, DELLAROSSA V, PARRA OO (1992) Growth and carotenogenesis in eight strains of Dunaliella salina Teodoresco from Chile. J appl Phycol 4: 111-118

CIFUENTES AS, GONZÁLEZ MA, PARRA OO (1996a) The effect of salinity on the growth and carotenogenesis in two Chilean strains of Dunaliella salina Teodoresco. Biol Res 29: 227-236 
CIFUENTES AS, GONZÁLEZ MA, PARRA OO, ZÚÑIGA M (1996b) Cultivo de cepas de Dunaliella salina (Teodoresco 1905) en diferentes medios de cultivo bajo condiciones de laboratorio. Rev Chilena Historia Natural 69: 105-112

CIFUENTES AS, GONZÁLEZ MA, INOSTROZA I, AGUILERA A (2001) Reappraisal of physiological attributes of nine strains of Dunaliella (Chlorophyceae): growth and pigment content across a salinity gradient. J Phycol 37: 334-344

CORDERO B, OTERO A, PATIÑO M, ARREDONDO BO, FABREGAS J (1996) Astaxanthin production from the green alga Haematococcus pluvialis with different stress conditions. Biotechnology Letters 18: 213-218

DAVIES BH (1976) Carotenoids. In: GOODWIN TW (ed) Chemistry and Biochemistry of Plants Pigments, Vol. 2. 2nd Edition. London: Academic Press. pp: 38-165

DROOP MR (1961) Haematococcus pluvialis and its allies III. Organic nutrition. Rev Algol N S 4: 247-259

ELLIOT AM (1934) Morphology and life history of Haematococcus pluvialis. Arch Protistenk 82: 250272

FAN L, VONSHAK A, BOUSSIBA S (1994) Effect of the temperature and irradiance on growth of Haematococcus pluvialis (Chlorophyceae). J Phycol 30: 829-833

GÓMEZ P, GONZÁLEZ MA, BECERRA J (1999) Quantity and quality of $\beta$-carotene produced by two strains of Dunaliella salina (Todoresco 1905) from the north of Chile. Bol Soc Chil Quim 44: 463-468

GONG X, CHEN F (1997) Optimization of culture medium for growth of Haematococcus pluvialis. J appl Phycol 9: 437-444

GRÜNEWALD K, HAGEN C, BRAUNE W (1997) Secondary carotenoid accumulation in flagellates of the green alga Haematococcus lacustris. Eur J Phycol 32: 387-392

GRUNG M, D'SOUZA M L, BOROWITZKA M, LIAAENJENSEN S (1992) Algal Carotenoids 51. Secondary Carotenoids 2. Haematococcus pluvialis aplanospores as a sourse of (3S, 3'S)-astaxanthin esters. J appl Phycol 4: 165-171

GUILLARD RRL (1973) Division rates. In: STEIN JR. (ed) Handbook of Phycological Methods. Culture Methods and Growth Measurements. London: Cambridge University Press. pp: 289-311

HAGEN C, BRAUNE W, GREULICH F (1993) Functional aspects of secondary carotenoids in Haematococcus lacustris (Girod) Rostafinski (Volvocales) IV. Protection from photodynamic damage. J Photochem Photobiol Biol. 20: 153-160

HAGEN C, GRUNEWALD K, SCHMIDT S, MULLER J (2000) Accumulation of secondary carotenoids in flagellates of Haematococcus pluvialis (Chlorophyta) is accompanied by an increase in per unit chlorophyll productivity of photosynthesis. Eur J Phycol 35: 75 82

HAGEN C, GRUNEWALD K, XYLANDER M, ROTHE E (2001) Effect of cultivation parameters on growth and pigment biosynthesis in flagellated cells of Haematococcus pluvialis. J appl Phycol. 13: 79-87

HARKER M, TSAVALOS AJ, YOUNG AJ (1995) Use of response surface methodology to optimize carotenogenesis in the microalga Haematococcus pluvialis. J appl Phycol 7: 399-406
HARKER M, TSAVALOS AJ, YOUNG AJ (1996a) Autotrophic growth and carotenoid production of Haematococcus pluvialis in a 30 liter air-lift photobioreactor. J Ferment Bioeng 82: 101-106

HARKER M, TSAVALOS AJ, YOUNG AJ (1996b) Factors responsible for astaxanthin formation in the chlorophyte Haematococcus pluvialis. Bioresourse Technology 55: 207-241

HATA N, OGBONNA JC, HASEGAWA Y, TARODA H, TANAKA H (2001) Production of astaxanthin by Haematococcus pluvialis in a sequencial heterotrophic-photoautotrophic culture. J appl Phycol 13: 395-402

JOHNSON EA, SCHROEDER WA (1995) Microbial carotenoids. In: FIECHTER (ed) Advances in Biochemical Engineering. Berlin: Springer. pp: 119178

KAKIZONO T, KOBAYASHI M, NAGAI S (1992) Effect of $\mathrm{C} / \mathrm{N}$ on encystment accompanied with astaxanthin formation in a green alga Haematococcus pluvialis. J Ferment Bioeng. 74: 403-405

KOBAYASHI M, KAKIZONO T, NAGAI S (1991) Astaxanthin production by a green alga Haematococcus pluvialis accompanied with morphological changes in acetate media. J Ferment Bioeng 71: 335-339

KOBAYASHI M, KAKIZONO T, NAGAI S (1993) Enhanced carotenoid byosynthesis by oxidative stress in acetate-induced cyst cells of a green unicellular alga, Haematococcus pluvialis. Applied and Environmental Microbiology 59: 867-873

KOBAYASHI M, KAKIZONO T, NISHIO N, NAGAI S (1992) Effects of light intensity, light quality and illumination cycle on astaxanthin formation in a green alga Haematococcus pluvialis. J Ferment Bioeng 74: 61-63

KOBAYASHI M, KAKIZONO T, NISHIO N, NAGAI S, KUKIMURA Y, TSUJI Y (1997a) Antioxidant role of astaxanthin in the green alga Haematococcus pluvialis. Appl Microbiol Biotechnol 48: 351-356

KOBAYASHI M, KURIMURA Y, TSUJI Y (1997b) Lightindependent, astaxanthin production by the green microalga Haematococcus pluvialis under salt stress. Biotechnology Letters 19: 507-509

KRISHNA K B, MOHANTY P (1998) Secondary carotenoid production in green algae. J Sci Industr Res 57: 51-63

LEE Y K, DING SY (1994) Cell cycle and accumulation of astaxanthin in Haematococcus lacustris (Chlorophyta). J Phycol 30: 445-449

LEE Y K, DING SY (1995) Effect of dissolved oxygen partial pressure on the accumulation of astaxanthin in chemostat cultures of Haematococcus lacustris (Chlorophyta). J Phycol 31: 922-924

LEE Y K, SOH CH-W (1991) Accumulation of astaxanthin in Haematococcus lacustris (Chlorophyta). J Phycol 27: 575-577

MARGALITH PZ (1999) Production of ketocarotenoids by microalgae. Appl Microbiol Biotechnol 51: 431438

MEYERS SP (1994) Developments in world aquaculture, feed formulations and role of carotenoids. Pure Appl Chem 66: 1069-1076

MIKI W (1991) Biological functions and activities of animal carotenoids. Pure Appl Chem 63: 141-146 
OLAIZOLA M (2000) Commercial production of astaxanthin from Haematococcus pluvialis using 25,000-liter outdoor photobioreactors. J appl Phycol 12: 499-506

OROSA D, FRANQUEIRA D, CID A, ABALDE J (2001) Carotenoid accumulation in Haematococcus pluvialis in mixotrophic growth. Biotechnology Letters 23: 373-378

PRINGSHEIM EG (1966) Nutritional requirements of Haematococcus pluvialis and related species. J Phycol 2: $1-7$

PROCTOR VW (1957) Some controlling factors in the distribution of Haematococcus pluvialis. Ecol 38: 457-462

SANTOS FM, MESQUITA JF (1984) Ultraestructural study of Haematococcus lacustris (Girod) Rostafinski (Volvocales). I. Some aspects of carotenogenesis. Cytologia 49: 215-228

SARADA R, TRIPATHI U, RAVISHANKAR GA (2002) Influence of stress on astaxanthin production in Haematococcus pluvialis grown under different culture conditions. Process Biochemistry 37: 623627

SPENCER KG (1989) Pigmentation supplements for animal feed compositions. U.S. patent $\mathrm{N}^{\circ} 4,871,551$

STARR RC, ZEIKUS JA (1987) UTEX-The culture collection of algae at the University of Texas at Austin. J Phycol 29: 1-106

STRICKLAND JDH, PARSONS TR (1972) A manual of seawater analysis. Bull Fish Res Bd Can 125: 1-310
STROSS RG (1963) Nitrate preference in Haematococcus as controlled by strain, age of inoculum, and $\mathrm{pH}$ of the medium. Can J Microbiol 9: 33-40

SUN Z, CUNNINGHAM FX, GANTT E (1998) Differential expression of two isopentenyl pyrophosphate isomerases and enhanced carotenoid accumulation in a unicellular chlorophyte. Proc Natl Acad Sci USA 95: 11482-11488

TJAHJONO AE, KAKIZONO T, HAYAMA Y, NISHIO N, NAGAI S (1994) Isolation of resistant mutants against carotenoid biosynthesis inhibitors for a green alga Haematococcus pluvialis, and their hybrid formation by protoplast fusion for breeding of higher astaxanthin producers. J Ferment Bioeng 77: 352-357

TRIKI A, MAILLARD P, GUDIN C (1997) Gametogenesis in Haematococcus pluvialis Flotow (Volvocales, Chlorophyta). Phycologia 36: 190-194

TRIPATHI U, SARADA R, RAMACHANDRA RS, RAVISHANKAR GA (1998) Production of astaxanthin in Haematococcus pluvialis cultured in various media. Biores Technol 68:197-199

VERGARA M (2002) Determinación de astaxantina por HPLC en muestras de Haematococcus pluvialis Flotow (Chlorophyta), cultivado en condiciones de laboratorio. (undergraduate thesis to obtain the degree of Chemical Analyst)

ZLOTNIK I, SUKENIK A, DUBINSKY Z (1993) Physiological and photosynthetic changes during the formation of red aplanospores in the chlorophyte Haematococcus pluvialis. J Phycol 29: 463-469 